\title{
Impacts of Anthropogenic Water Withdrawals on the Hydropower Potential of the Ouémé River at the 2040's Horizon in Benin
}

\author{
Télesphore Cossi Nounangnonhou ${ }^{1,2, ~ *, ~ F r a n c ̧ o i s-X a v i e r ~ N i c o l a s ~ F i f a t i n ~}{ }^{1}$, Amevi Acakpovi ${ }^{3}$, \\ Emile Adjibadé Sanya ${ }^{2}$ \\ ${ }^{1}$ Department of Electrical Engineering, University of Abomey-Calavi, Calavi, Benin \\ ${ }^{2}$ Department of Mechanical and Energetic Engineering, University of Abomey-Calavi, Calavi, Benin \\ ${ }^{3}$ Department of Electrical and Electronic Engineering, Accra Technical University, Accra, Ghana
}

Email address:

nocteles2000@gmail.com (Télesphore C. N.), fifatinf $a$ gmail.com (François-Xavier N. F.),

acakpovia@gmail.com (Amevi A.), easanyas@hotmail.com (Emile A. S.)

${ }^{*}$ Corresponding author

\section{To cite this article:}

Télesphore Cossi Nounangnonhou, François-Xavier Nicolas Fifatin, Amevi Acakpovi, Emile Adjibadé Sanya. Impacts of Anthropogenic Water Withdrawals on the Hydropower Potential of the Ouémé River at the 2040's Horizon in Benin. Journal of Water Resources and Ocean Science. Vol. 8, No. 1, 2019, pp. 1-8. doi: 10.11648/j.wros.20190801.11

Received: December 20, 2018; Accepted: January 10, 2019; Published: February 13, 2019

\begin{abstract}
Hydropower is one of the major renewable energy resources worldwide faces challenges day after day. Climate change and anthropogenic pressures can have negative impacts on hydropower production. This paper considers reservoirdams in the GR2M hydrological model in order to simulate the impacts of anthropogenic water withdrawals on the hydropower potential of the Ouémé River basin (Benin) by 2040. The rain-flow model, GR2M of the National Institute for Research in Science and Technology for Environment and Agriculture (IRSTEA) is used to estimate the impacts of two scenarios of future water withdrawals on the hydropower potential of the Ouémé River. Water withdrawals taken respectively at the Bétérou, Savè and Kétou sites, representing the Ouémé River, using multifunction tanks and mixed tanks were carefully analyzed. The results obtained show that the mixed reservoir scenario is more tolerant to water withdrawals compared to the multi-function reservoir scenario regardless of the site considered. In addition, high sensitivity of the hydropower potential to annual water withdrawals was observed at Bétérou, which was relatively lower at the Savè and Kétou sites. Moreover, with the mixed reservoir scenario, Savè and Kétou sites show stability in their production at water withdrawals rates lesser than $10 \%$ and $20 \%$ respectively. This study highlights the importance of the Ouémé basin's potential, the exploration of which would constitute a strong link in the development strategy of energy and hydro-agricultural sectors of Benin Republic.
\end{abstract}

Keywords: Hydropower, Climate Change, GR2M, Anthropogenic Water Withdrawals, Ouémé River

\section{Introduction}

In his perpetual pursuit of well-being, mankind has destabilized the planet earth equilibrium by emitting excessive greenhouse gases into the atmosphere. Consequently, there is an acceleration of extreme weather phenomena due to the destruction of the ozone layer. Despite the fact that some natural processes lead to environmental and climatic changes, current research indicates that these processes are insignificant compared to man-made processes
[1].

In tropical Africa, surface water resources dependent on verry irregular rainfall over time and space, are becoming increasingly limited due to climatic deterioration [2]. Subsequently, this region of Ouémé (Benin), is exposed to chronic food crises due to drought and floods. To adapt to it, many West African countries adopted integrated water resources management policy by setting up dams, not only to regulate the flow of watercourses but especially for the promotion of irrigated agriculture with a view to averting food crises. In fact, in Benin, the Ouémé basin alone 
accounts for about $45 \%$ of the 13 billion cubic meters $\left(\mathrm{m}^{3}\right)$ of surface water and $60 \%$ of the 2 billion $\mathrm{m}^{3}$ of annual recharge of groundwater [3]. This represents a strong hydroelectric and agricultural potential but also a strong threat for coastal cities, particularly in terms of flood risk. On the Ouémé basin, there is still no hydropower production facility. A study was conducted in 1992 on the optimal development of Ouémé River hydropower potential [4]. The results led to the selection of eight construction sites for hydroelectric dams. The impacts of dams in general and anthropogenic pressures in particular on river flows are specific to watersheds and management objectives (flood capping, irrigation, hydroelectricity) and also to the type of climate $[5,6]$. Hydrological studies addressing the issue of surface water withdrawals aim to analyze the impacts of one or more dams on the hydrological behavior of a given watershed, but few syntheses or general exist [7]. The embryonic state of research in this area is mainly due to the lack of a reliable scientific quantification method of water withdrawals. To date, two conventional approaches have been used to estimate water withdrawals. The first approach distributes water withdrawals uniformly throughout the year [8], which is unrealistic in the current climate change contexts where spatial and temporal variability of water needs are very obvious. The second uses the standards defined by the FAO per unit and type of use. The bias associated with this approach is according to Hughes and Mantel [9], the invariability of this norm in time and space by type of use and also the scarcity of reliable information on the number and type of use. To circumvent these shortcomings to a limited extent, it is proposed in this work, the establishment of a method of correlation between sampling and monthly evapotranspiration for taking into account water requirements in the GR2M model.

A large number of modelling and simulation of the hydrological cycle have been carried out on the Ouémé basin in Benin $[3 ; 10]$. As part of the Ouémé-2025 project, several hydrological models have been applied, but only the gobal GR2M model has proved satisfactory at the basin scale by its robustness and by its results $[10,11]$. These results were similar to those obtained on the same historical data by Vodounnon [12] and Lawin et al. [13]. The main gap identified in the previous studies is their failure to consider the impacts of climate change and possible anthropogenic pressures. Indeed, the problem of the behavior of the hydrological regime and the water resources management of the Ouémé River includes the dimensions of the evolution of climate and human activities. The climatic dimension is concerned with the way in which the variability of climatic parameters and their impacts on the Ouémé basin are manifested [14]. This study aims to highlight the impacts of anthropogenic surface water withdrawals on the hydropower potential of the Ouémé basin by 2040 . It is a question of integrating these collected water, restored or not, into the model GR2M in order to simulate their impacts on the hydropower production of the sites of Bétérou (in Bétérou Amont), Savè (in Béthel-Bis) and Kétou (in Dogo), three representative sites of the Ouémé basin in Benin.

\section{Material and Methods}

\subsection{Study Area}

The Ouémé basin (Figure 1) covers an area of $47,000 \mathrm{~km}^{2}$, about $43 \%$ of the country's surface [15]. Located between 6.8 and $10.2^{\circ}$ Latitude North, the Ouémé basin is characterized by a transition from the Sudanese climate in the North with an average of 900 to $1000 \mathrm{~mm}$ of precipitation per year, the climate of Benin in the south with $1200 \mathrm{~mm}$ of rain per year on average. About $89 \%$ of the Ouémé River basin is located in Benin, $10 \%$ in Nigeria and $1 \%$ in Togo [16]. Its basin has an average annual temperature of 26 to $30^{\circ} \mathrm{C}$ [16]. From a hydrological point of view, this basin is characterized by lower and lower water flows and the early drying up of seasonal courses [17]. The Ouémé River is $510 \mathrm{~km}$ long and leads to two considerable affluents (Okpara and Zou). It flows towards Lake Nokoué $(150 \mathrm{~km} 2)$ and falls into the sea through the coastal lagoon [18].

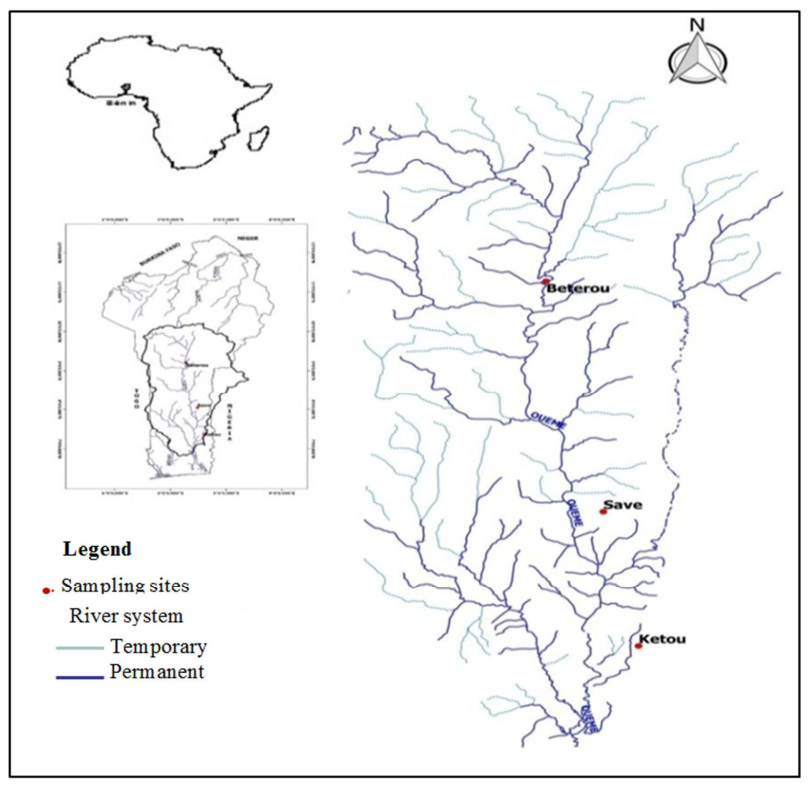

Figure 1. Description of Basin flowing from Ouémé River and location of the 3 representative sites.

\subsection{Data Used}

The data used in this work are listed as follows: average monthly flow, monthly average water height, the height of natural drop, the monthly average evapotranspiration and the average monthly electrical potential of the three representative sites of the different areas of the Ouémé River namely Bétérou, Savè and Kétou. The collected data covers the periods from 2017 to 2040. They come from research carried out on the Ouémé River at the 2040's horizon by Nounangnonhou et al. [19]. Due to the unavailability of a reliable database on water withdrawals in the Ouémé River basin, a database that can be used to model and predict future trends, a series of forecast based on water withdrawals taken 
in the year 2011 alone were therefore used in the present study: $221,000,000 \mathrm{~m}^{3}$ in Bétérou [3], 4,200,000 $\mathrm{m}^{3}$ in Savè and $3,000,000 \mathrm{~m}^{3}$ in Kétou [20]. These values were used to simulate the future behavior of the hydropower potential of the river basin.

\subsection{Methods}

Based on annual water withdrawals data from 2011 in Bétérou [3], Savè and Kétou [20], monthly water requirements (monthly water withdrawals) were generated from the monthly coefficients of potential evapotranspiration (PET), previously determined by the arithmetic mean method. This methodology is based on an assumption of the existence of a strong correlation between the potential evapotranspiration and the needs of water withdrawals intended for irrigation because the soils are considered to be rocky type with very low permeability to water $[21 ; 22]$. Thus, the water requirements determined are the monthly water withdrawals $\left(Q_{p}\right)$ to be used as input to the GR2M rainflow model developed by the National Research Institute of Science and Technology for the Environment and Agriculture (IRSTEA) that takes into consideration water withdrawals [23].

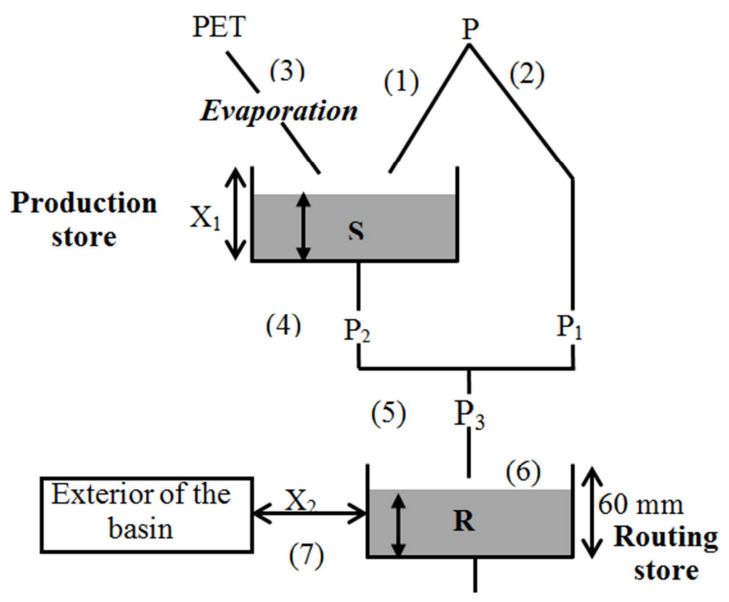

(8) $\mathrm{O}$

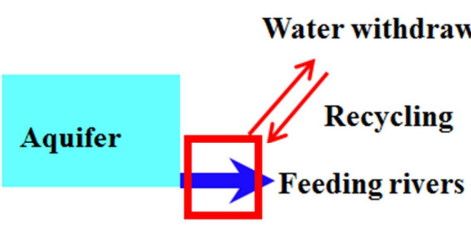

Immediate impact on the flow
Water withdrawals in aquifers

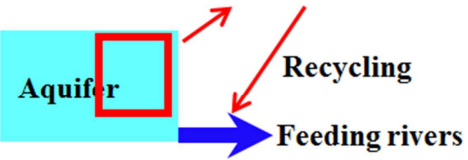

Delayed impact on the flow (Acceleration of the natural

Figure 2. IRSTEA'S GR2M rain-flow model with consideration of anthropogenic water withdrawals [23].

The water deriving from the average monthly precipitation (P) and discharges into the basin (Figure 2) is subdivided into water intercepted by the plants, water retained by the soil, infiltrated water and water flowing at the surface [24]. All of the intercepted water and some of the water retained by the soil are lost through evaporation and transpiration [25]. Excess water flowing over the surface contributes significantly to the outfall flow (Q). It is divided between a more direct path $\mathrm{P} 1$ and the production reservoir having a filling level $\mathrm{S}$ and a maximum capacity $\mathrm{X}_{1}$. A portion of the reservoir water is used to meet the evapotranspiration demand and a quantity $\mathrm{P}_{2}$ infiltrates into the soil, thus adding to $P_{1}$ to form $P_{3}$ with a fill level $R$. This reservoir can gain or lose water with the outside of the basin according to the coefficient of underground exchanges $X_{2}$. It empties according to a quadratic function to form the flow (Q) of the watercourse. The parameters $X_{1}$ and $X_{2}$ are determined by forcing the model by the chronicity of rain and potential evapotranspiration by a calibration on the observed flows.

With this model, water withdrawals made in the river basin have a direct impact, they can modify the flow of the river. For the volumes pumped in the aquifers, the impact is different with an extraction which is carried out at the level of the routing reservoir $\mathrm{R}$ as indicated in Figure 2. However, the hydrogeological formations of the middle and upper subbasins of the Ouémé (study area) consist of two types of groundwater. The first type is located in the sandy-clayey alteration zone with a thickness generally of the order of 10 to $30 \mathrm{~m}$. Their accessibility is very difficult because the permeability of these zones is very low and often in the order of $8.10^{-6} \mathrm{~m} / \mathrm{s}$ [26].

The second type is located in the crystalline basement which does not contain a continuous aquifer because of the absence of porosity. These rocks are almost impervious if they are not cracked or altered [3]. Because of these constraints, most previous studies are based on surface water catchment. In view of the challenges with the two types of groundwater described above, it can be considered that the quantities of water extracted in the aquifers are negligible compared to the quantities taken from surface water. To 
evaluate the impact of the water withdrawals on the hydropower production, two scenarios were simulated.

The first scenario is based on the analysis of the behavior of a single multipurpose dam towards the impacts of climate change and anthropogenic water withdrawals of low water. This scenario is conceived around the hydroelectric dams of Bétérou, Savè and Kétou as the only ones to satisfy all the surface water needs in time and space by having as main function-objective the hydropower production.

The second, described as a mixed reservoir scenario, is based on the creation of intermediate reservoirs between multipurpose dams on the river and its affluents. These intermediate dams are then intended to collect excess water during periods of flood and water directed by multipurpose dams during periods of low water, for mainly agricultural and domestic uses when needed and especially during periods of drought.

For each scenario, the obtained flows $Q_{i}$ after the water withdrawals, are used to determine the annual potential hydropower energy $\mathrm{E}(\mathrm{GWh})$ defined by:

$$
E(G W h)=\sum_{i=1}^{i=12} P\left(Q_{i}, H_{i}\right) . T_{i}
$$

Where $P\left(Q_{i}, H_{i}\right)$ is the monthly potential electric power [27] expressed in Gigawatt (GW) as follows:

$$
\begin{gathered}
P\left(Q_{i}, H_{i}\right)=\frac{9.81 \cdot Q_{i} \cdot H_{i}}{1000} \\
H_{i}=h_{0}+h_{i}
\end{gathered}
$$

With:

$\mathrm{Q}_{\mathrm{i}}$ : average monthly interannual flow of month i expressed in cubic meters per second $\left(\mathrm{m}^{3} / \mathrm{s}\right)$;

$H_{i}$ : the total water drop (difference between the upstream level and the downstream level of the plant,

$\mathrm{T}_{\mathrm{i}}$ the production time associated with the rate $\mathrm{Q}_{\mathrm{i}}$ expressed in hours $(\mathrm{h})$,

$h_{0}$ : the natural fall of the hydroelectric plant (natural elevation of the site)

$h_{i}$ : the height of water upstream of the water reservoir

Finally, for the evaluation of annual potential hydropower generation, the following constraints have been considered:

If

$$
\begin{gathered}
Q_{i} \geq 1.25 . Q_{n}, E(G W h)=\sum_{i=1}^{i=12} P\left(Q_{n}, H_{i}\right) . T_{i} \\
Q_{n} \leq Q_{i}<1.25 . Q_{n}, E(G W h)=\sum_{i=1}^{i=12} P\left(0.8 . Q_{i}, H_{i}\right) . T_{i}
\end{gathered}
$$

If

$$
Q_{i}<Q_{n} P\left(Q_{i}, H_{i}\right)=0 \text { et } T_{i}=0
$$

With $\mathrm{Q}_{\mathrm{n}}$ the nominal flow rate of the hydraulic turbine installed.

\section{Results and Discussions}

In this part, we first present the results recorded following the application of multifunction scenario procedure on each of the three reference sites of the Ouémé River basin, followed by their interpretation. This scenario derives from the construction of three large multipurpose hydroelectric dams on the Ouémé River, namely: Kétou (Dogo), Savè (Bethel-Bis) and Bétérou (Bétérou Amont). In this scenario, all possible water withdrawals are made in the dam intended for the production of electricity and especially during periods of low water and drought. The second part presents the results and discussion of the scenario labelled mixed, which includes, in addition to the three large multipurpose hydropower dams, the construction of a number of small dams on the affluent in order to receive excess water withdrawals during floods. These volumes of water withdrawals are therefore used for hydropower production but are instead intended for other uses (agricultural, domestic, etc.).

\subsection{Multifunction Scenario}

Figures 3.a, 3.b and 3.c show respectively on the sites of Bétérou, Savè and Kétou, the curves of evolution of the hydropower potential of the Ouémé River according to the rates of water withdrawals applied. The rate $\mathrm{T}=0 \%$ is used to display the reference curve, which is the obtained hydropower potential on the assumption that, there has been no water withdrawal from the river.

In the Figure 3, it became clear with this scenario, that water withdrawals in the Ouémé basin is likely to reduce the hydropower production capacity of all the sites under consideration, but to some varying degrees. For rates lower than $5 \%$ and $20 \%$, water withdrawals will have almost no impact on electricity production respectively in Savè and Kétou.

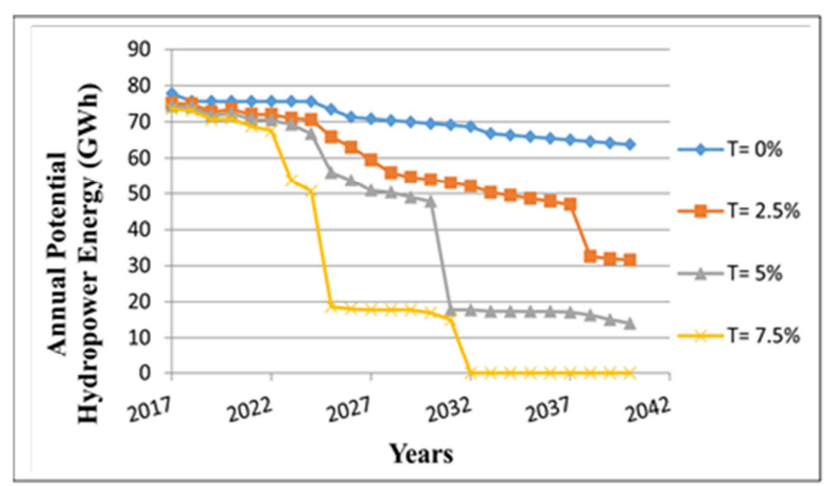

a)

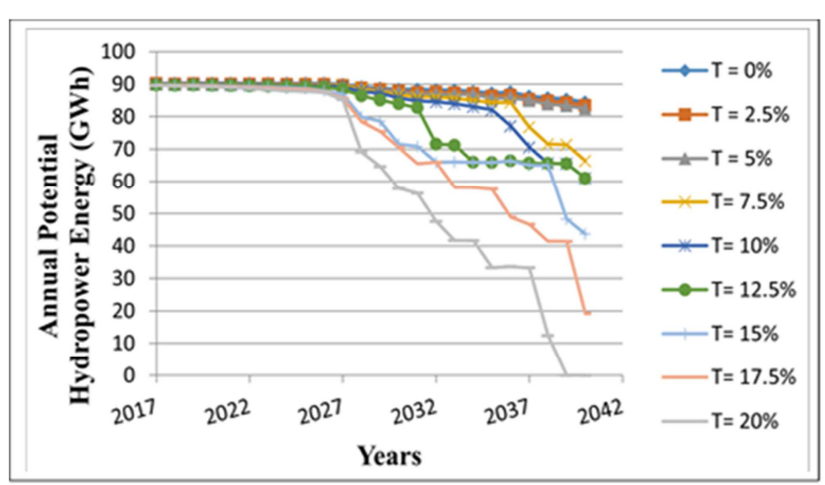

b) 


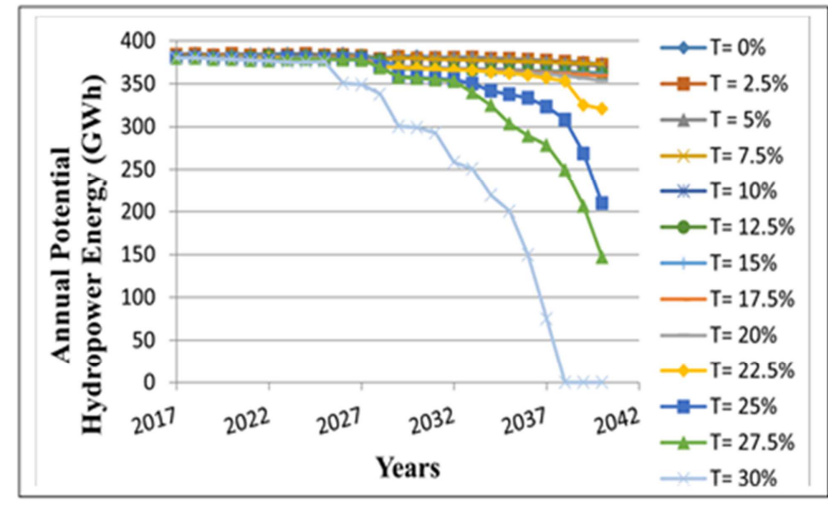

c)

Figure 3. Simulation of the annual hydropower potential of the Ouémé River according to the water withdrawals rates using the multifunctional scenario. a) Case of the Bétérou site; b) Case of the Savè site; c) Case of the Kétou site.

Unlike these two sites, Bétérou site shows more sensitivity to the water withdrawals, even at a rate of $2.5 \%$. This may be due not only to the direct impact of climate change (reduction of rainfall and elevation of ETP) which has considerably reduced the hydrology of the Ouémé River to Bétérou [3; 10] but also to the current volumes of water withdrawals that are huge in Northern Benin (221 million cubic meters in 2011). It is equally important to note that, the year 2028 turns out to be a year of rupture where electricity production has declined regardless of the rate of water withdrawals for all the sites. This is noticed on the reference signals $(\mathrm{T}=0 \%)$ but the decrease is very pronounced for the rates higher than $12.5 \%$ and $25 \%$ on the sites of Savè and Kétou respectively. Finally, the sites of Savè and Kétou offer water withdrawals possibilities relatively higher than that of Bétérou. The highest collection rate is $30 \%$ in Kétou. This high percentage could be explained first by the density of the hydrology of the production site and secondly by the weakness of the current quantities of water withdrawals in this region which is located in the upstream side of the majority of irrigable perimeters of the Ouémé River.

Table 1 shows the reduction that would be generated over the period 2017 to 2040 by the anthropogenic water withdrawals on the hydropower production of the Béterou, Savè and Kétou sites of the Ouémé River.

Table 1. Hydropower potential reductions caused by future water withdrawals at the Bétérou, Savè and Kétou sites according to the multifunctional scenario.

\begin{tabular}{|c|c|c|c|c|c|c|c|}
\hline \multirow{3}{*}{ Units } & \multirow[b]{2}{*}{$\begin{array}{l}\text { Rate of } \\
\text { water with } \\
\text { drawals }\end{array}$} & \multicolumn{2}{|l|}{ Bétérou Site } & \multicolumn{2}{|l|}{ Savè Site } & \multicolumn{2}{|l|}{ Kétou Site } \\
\hline & & $\begin{array}{l}\text { Average annual } \\
\text { hydropower } \\
\text { production } \\
(2017-2040) \\
\end{array}$ & $\begin{array}{l}\text { Average } \\
\text { reduction on } \\
\text { hydropower } \\
\text { production } \\
\end{array}$ & $\begin{array}{l}\text { Average annual } \\
\text { hydropower } \\
\text { production } \\
(2017-2040) \\
\end{array}$ & $\begin{array}{l}\text { Average } \\
\text { reduction on } \\
\text { hydropower } \\
\text { production } \\
\end{array}$ & $\begin{array}{l}\text { Average annual } \\
\text { hydropower } \\
\text { production } \\
(2017-2040) \\
\end{array}$ & $\begin{array}{l}\text { Average } \\
\text { reduction on } \\
\text { hydropower } \\
\text { production } \\
\end{array}$ \\
\hline & $\%$ & GWh & $\%$ & GWh & $\%$ & GWh & $\%$ \\
\hline & 2.5 & 57.49 & 18.50 & 88.15 & 0.64 & 380.55 & 0.27 \\
\hline & 5 & 43.55 & 38.26 & 87.78 & 1.05 & 380.00 & 0.41 \\
\hline & 7.5 & 27.13 & 61.54 & 85.34 & 3.81 & 379.11 & 0.64 \\
\hline & 10 & - & - & 83.55 & 5.83 & 373.74 & 2.05 \\
\hline & 12.5 & - & - & 80.03 & 9.79 & 373.06 & 2.23 \\
\hline & 15 & - & - & 76.35 & 1.95 & 372.98 & 2.25 \\
\hline & 17.5 & - & - & 70.94 & 20.04 & 372.25 & 2.44 \\
\hline & 20 & - & - & 60.98 & 31.27 & 371.20 & 2.72 \\
\hline & 22.5 & - & - & - & - & 367.43 & 3.71 \\
\hline & 25 & - & - & - & - & 351.49 & 7.88 \\
\hline & 27.5 & - & - & - & - & 337.21 & 11.62 \\
\hline & 30 & - & - & - & - & 270.09 & 29.21 \\
\hline
\end{tabular}

As shown in Table 1 , when the $7.5 \%$ retention rate of the 2011 reference value is maintained, Bétérou's production will fall by $61.54 \%$ over the $2017-2040$ with a production shutdown in 2032. At the same rate of $7.5 \%$, the Savè and Kétou stations will show a decrease of $3.81 \%$ and $0.64 \%$ respectively. These results confirm that the latter two sites are insensitive to low water withdrawals rates, unlike that of Bétérou. In addition, it appears that the Savè plant will cease electricity production in 2039 when its dam will be subject to the average annual rate of $20 \%$ water withdrawals (compared to the 2011 water requirements). At this same rate however, the production in Kétou seems stable with a drop of $2.72 \%$. This confirms the robustness of the Kétou site. However, when the Kétou site would be subject to an average annual water withdrawals rate of about $30 \%$, its production would be strongly impacted to the point where it will not be profitable to produce electricity from the year 2038 which marks the probable cessation of production in Kétou. To improve the phenomena observed at these three sites, another alternative has been explored: the mixed scenario.

\subsection{Mixed Scenario}

Figure 4 presents the evolution of the hydropower production potential of the three representative sites of the Ouémé River according to the water withdrawals taken in the period from 2017 to 2040 . This figure reveals, as in the case of the multifunctional scenario, that the sensitivity of the hydropower production to anthropogenic water withdrawals is not the same in comparison with the multifunction scenario. 


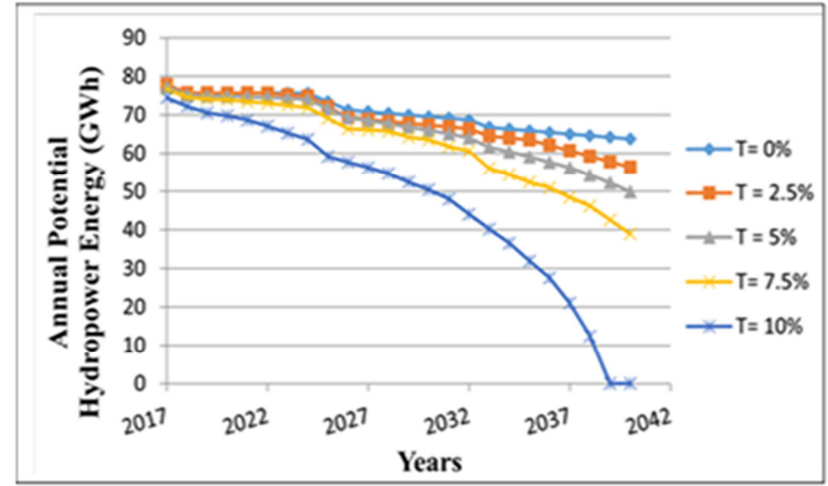

a)

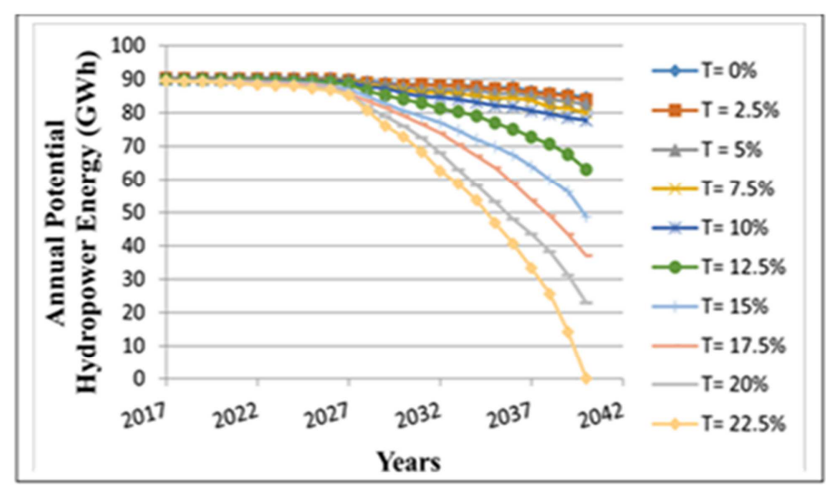

b)

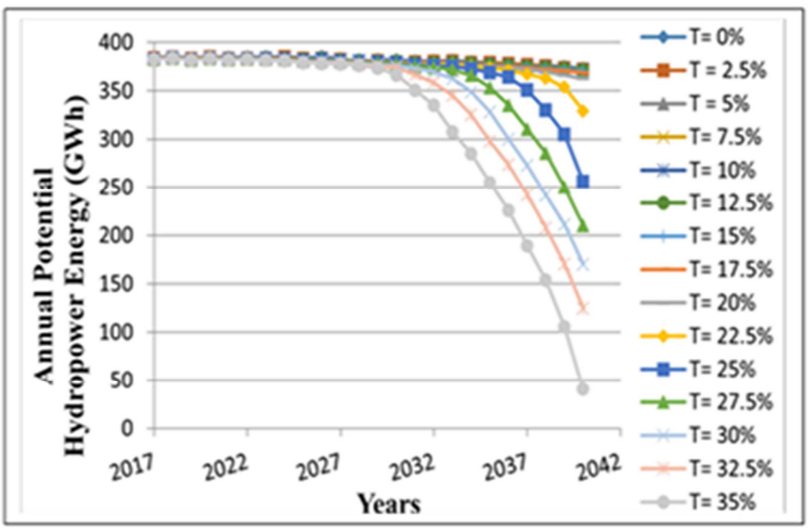

c)

Figure 4. Simulation of the annual hydropower potential of the Ouémé River according to the water withdrawals rates according to the mixed scenario.

a) Case of the Bétérou site; b) Case of the Savè site; c) Case of the Kétou site With the mixed scenario, the different hydropower production curves are closer to each other, contrary to what is observed in the multifunction scenario. The scenario makes the Bétérou power station less sensitive to water withdrawals rates of less than or equal to $7.5 \%$. This implies a significant increase in water volumes that could be collected at all hydropower generating sites in the Ouémé River Basin and in Bétérou particularly, without a remarkable degradation of the hydropower potential.

Table 2. Hydropower potential reductions caused by future water withdrawals at the Bétérou, Savè and Kétou sites according to the mixed scenario.

\begin{tabular}{|c|c|c|c|c|c|c|c|}
\hline \multirow{3}{*}{ Units } & \multirow[b]{2}{*}{$\begin{array}{l}\text { Rate of } \\
\text { water with } \\
\text { drawals }\end{array}$} & \multicolumn{2}{|l|}{ Bétérou Site } & \multicolumn{2}{|l|}{ Savè Site } & \multicolumn{2}{|l|}{ Kétou Site } \\
\hline & & $\begin{array}{l}\text { Average annual } \\
\text { hydropower } \\
\text { production } \\
(2017-2040) \\
\end{array}$ & $\begin{array}{l}\text { Average } \\
\text { reduction on } \\
\text { hydropower } \\
\text { production } \\
\end{array}$ & $\begin{array}{l}\text { Average annual } \\
\text { hydropower } \\
\text { production } \\
(2017-2040) \\
\end{array}$ & $\begin{array}{l}\text { Average } \\
\text { reduction on } \\
\text { hydropower } \\
\text { production } \\
\end{array}$ & $\begin{array}{l}\text { Average annual } \\
\text { hydropower } \\
\text { production } \\
(2017-2040) \\
\end{array}$ & $\begin{array}{l}\text { Average } \\
\text { reduction on } \\
\text { hydropower } \\
\text { production } \\
\end{array}$ \\
\hline & $\%$ & GWh & $\%$ & GWh & $\%$ & GWh & $\%$ \\
\hline & 2.5 & 68.40 & 3.04 & 88.39 & 0.37 & 380.55 & 0.27 \\
\hline & 5 & 66.27 & 6.05 & 87.78 & 1.05 & 380.05 & 0.40 \\
\hline & 10 & 47.68 & 32.41 & 85.97 & 3.09 & 379.91 & 0.43 \\
\hline & 12.5 & - & - & 82.83 & 6.64 & 379.77 & 0.47 \\
\hline & 15 & - & - & 79.00 & 10.95 & 379.54 & 0.53 \\
\hline & 17.5 & - & - & 75.53 & 14.86 & 379.12 & 0.64 \\
\hline & 20 & - & - & 71.14 & 19.82 & 378.24 & 0.87 \\
\hline & 22.5 & - & - & 66.76 & 24.75 & 375.40 & 1.62 \\
\hline & 25 & - & - & - & - & 367.41 & 3.71 \\
\hline & 30 & - & - & - & - & 346.23 & 9.26 \\
\hline & 32.5 & - & - & - & - & 334.82 & 12.5 \\
\hline & 35 & - & - & - & - & 314.86 & 17.48 \\
\hline
\end{tabular}

As shown in Table 2, the maximum collection rates in Bétérou, Savè and Kétou are respectively $7.5 \%, 20 \%$ and $30 \%$ for the multifunction scenario and $10 \%, 22.5 \%$ and $35 \%$ for the mixed scenario. Considering the new rates obtained with the mixed scenario, it is obvious that the decreases are considerably reduced by the application of the mixed scenario. The decreases changed from $61.54 \%, 31.27 \%$ and $29.21 \%$ to $11.52 \%, 19.82 \%$ and $9.26 \%$ respectively in Bétérou, Savè and Kétou sites, which can be expressed in relative reduction as $81.28 \%$ in Bétérou, $36.62 \%$ in Savè and $68.30 \%$ in Kétou. It is clear that the adoption of the mixed scenario brings a lot of improvements to the hydropower potential of the various sites in general and that of Bétérou and Kétou in particular. For rates of less than $10 \%$ and $20 \%$, the water withdrawals will have almost no major impact on the electrical production potential in Savè and Kétou respectively. In addition, a hydropower potential in Savè would experience a total shutdown of production of electricity in 2040, should the dam be subject to an average annual rate of $22.5 \%$. At these same water withdrawals, the Kétou site would know only a drop of $6.43 \%$. This predicts a better hydropower production performance on the latter. Even when the Kétou site would be 
subjected to an average annual rate of water withdrawals of about $35 \%$, its hydropower production would not be significantly impacted and this prediction indicates that until the year 2040, there will only be an average decrease in electricity production of $17.48 \%$. Comparing the two scenarios, it can be observed that the mixed scenario offers more possibilities of extracting water than the multifunctional scenario, regardless of the site considered. Indeed, the maximum water withdrawals rates are higher for the mixed scenario at the three respective sites: $10 \%$ in Béterou, $22.5 \%$ in Savè and $35 \%$ in Kétou compared to the multifunction scenario: $7.5 \%$ in Bétérou, $20 \%$ in Savè and 30\% in Kétou.

Notwithstanding this favorable performance for the mixed scenario, it is not advisable to exceed the annual water withdrawals thresholds, which are in fact average maximum values, of $320,000,000 \mathrm{~m}^{3}, 23,000,000 \mathrm{~m}^{3}$ and $120,000,000$ $\mathrm{m}^{3}$ respectively for Bétérou, Savè and Kétou sites over the period from 2017 to 2040. Any water withdrawals rates exceeding these maximum values might significantly impact the potentials and therefore the hydropower production of the hydroelectric plants to be constructed on these different sites.

\section{Conclusion}

At the end of this study, forecasts show that climate change will significantly affect the level of hydropower generation capacity. In addition, anthropogenic removals will also significantly affect the production of hydropower in the Ouémé basin, regardless of the scenario used in the two proposed in this study. However, the results allow to conclude that the mixed reservoir scenario is the most profitable on the study area. As a result, it is most recommended for any energy policy initiative or decision aimed at hydropower generation on the Ouémé River. However, this scenario would contribute to an increase in evapotranspiration and water infiltration into the soil. Our study could not address the impacts of groundwater abstraction on the hydropower potential of the study area. It is essential that future studies incorporate this parameter in order to reduce the margins of error in the prediction of the hydropower potential of this basin.

\section{Acknowledgements}

The Authors thank the officials of the Laboratory of Biomathematics and Forest Estimates (LABEF) of the University of Abomey-Calavi, for their scientific guidance.

\section{References}

[1] IPCC. Contribution of Working Group I to the Fourth Assessment Report of the Intergovernmental Panel on Climate Change, Report, Cambridge University Press, Cambridge, United Kingdom, 2007, pp. 18.

[2] Amoussou, E., Totin, V. S. H., Vissin, W. E., Mahé, G., Houndénou, C. and Boko, M. Modélisation pluie-débit pour la gestion intégrée des ressources en eau (GIRE) de surface dans le bassin de la Volta au Bénin, Revue de géographie du laboratoire Leïdi, ISSN $0851-2515, n^{\circ} 13,2015$, pp. 282-296.

[3] Zannou, A. Analyse et modélisation du cycle hydrologique continental pour la gestion intégrée des ressources en eau au Bénin: cas du bassin de l'Ouémé à Bétérou, Thèse de doctorat, Université d'Abomey-Calavi, Bénin, 2011, pp. 315.

[4] EDF. Etude de faisabilité de Kétou dans le cadre de l'aménagement hydroélectrique optimal du fleuve Ouémé, Rapport Final R6, Communauté Electrique du Bénin, 1992, pp 78.

[5] Williams, G. P. and Wolman, M. G. Downstream effects of dams on alluvial rivers. U.S. Geological Survey, 1984, pp. 83.

[6] Batalla, R. J., Gómez, C. M. and Kondolf, G. M. Reservoirinduced hydrological changes in the Ebro River basin (NE Spain), Journal of Hydrology, 290 (1-2), 2004, pp.117-136.

[7] Graf, W. L. Downstream hydrologic and geomorphic effects of large dams on American rivers. Geomorphology, 79 (3-4), 2006, pp. 336-360.

[8] Teoh, K. S. Estimating the Impact of Current Farm Dams Development on the Surface Water Resources of the Onkaparinga River Catchment, Report, DWLBC 202/22, Department of Water, Land and Biodiversity Conservation, South Australia, 2003, pp. 154.

[9] Hughes, D. A. and Mantel, S. K. Estimating the uncertainty in simulating the impacts of small farm dams on stream flow regimes in South Africa. Hydrological Sciences Journal, 55 (4), 2010, pp. 578-592.

[10] Nounangnonhou, C. T., Fifatin, F-X. N., Lokonon, B. E., Acakpovi, A. and Sanya, E. A. Modelling and Prediction of Ouémé (Bénin) River Flows by 2040 Based on GR2M Approach, Larhyss Journal, ISSN 1112-3680, n 33, 2018, pp. 71-91.

[11] Agbidinoukoun, A. S. Estimation des ressources en eaux superficielles à l'horizon 2025 dans l'Ouémé à Bétérou, Savè et le Zou à Atchérigbé à l'aide des modèles GR2M et GR4J. Mémoire de Master, 2iE, Ouagadougou, Burkina Faso, 2011, pp. 61.

[12] Vodounnon, J. Contribution à l'étude de la caractérisation hydro-pluviométrique du bassin de l'Ouémé avec le modèle GR2M. Mémoire de Maîtrise, FLASH/UAC, Abomey-Calavi Bénin, 2008, pp. 83.

[13] Lawin, A. E., Vissin, E., Sintondji, L., Gohoungossou, A., Vodounou, J-B., Zannou, A., Vodounnon, J., Ahouansou, M. et Abdoulaye, D. Contribution du Projet OUÉMÉ-2025 à l'étude de la dynamique et de la disponibilité des ressources du bassin de l'Ouémé: Résultats préliminaires, actes de conférence aux $5^{\text {èmes }}$ Journées Scientifiques du 2iE, Ouagadougou, Burkina Faso, 2009, pp. 7.

[14] Nounangnonhou, C. T., Fifatin, F.-X. N. and Sanya, E. A. Modélisation et simulation des paramètres climatiques à l'horizon 2040 sur le bassin du fleuve Ouémé en République du Bénin, Afrique Science, 12 (6), 2016, pp. 48-56.

[15] Barthel, R., Jagelke, J., Gaiser, T., Printz, A. and Götzinger, J. Aspects of choosing appropriate concepts for modelling groundwater resources in regional Integrated Water Resources Management, Examples from the Neckar (Germany) and Ouémé catchment (Benin), Phys. Chem. Earth, 33 (1-2), 2008, pp. 92-114. 
[16] Bossa, Y. A. Multi-scale modeling of sediment and nutrient flow dynamics in the Ouémé catchment (Benin), towards an assessment of global change effects on soil degradation andwater quality, Thesis $(\mathrm{PhD})$, University of Bonn, Germany, 2012, pp. 110.

[17] Lawin, A. E. Analyse climatologique et statistique du régime pluviométrique de la Haute Vallée de l'Ouémé à partir des données AMMA-CATCH Bénin, Thèse de Doctorat, Institut National Polytechnique de Grenoble, France, 2007, pp. 211.

[18] Diekkrüger, B., Busche, H., Giertz, S. and Steup, G. Hydrology, In: Impacts of Global Change on the Hydrological Cycle in West and Northwest Africa, Speth, P., Christoph, M. and Diekkrüger, B. (Eds.). Springer, Heidelberg, Germany, 2010, pp. 60-64.

[19] Nounangnonhou, C. T., Fifatin, F.-X. N., Aza-Gnandji. M. R., Acakpovi, A. and Sanya, E. A. Forecast of Impacts of Climate Change on Hydropower Potential of Ouémé River at the 2040's Horizon in Benin, International Journal of Energy and Power Engineering, 2018, 7 (1), pp. 6-18.

[20] SDAGE. Réalisation du schéma directeur d'aménagement et de gestion des eaux du bassin de l'Ouémé, Rapport, 2013, vol 1, pp. 94 .

[21] Faure, P. Carte pédologique de reconnaissance du Bénin au
$1 / 200.000^{\text {e: }}$ feuille de Djougou, ORSTOM, Paris (France), 1997, pp. 205.

[22] Faure, P. and Volkoff, B. Some factors affecting regional differentiation of the soils in the Republic of Benin (West Africa), Catena, 1998, pp. 281-306.

[23] CRESEB. Débit minimum biologique (DMB) et gestion quantitative de la ressource en eau, Guide version 0, 2015, pp. 124.

[24] Beven, K. J. Rainfall-runoff modeling: the primer, 2nd ed, John Wiley and sons, Chichester, England, 2001, pp. 360.

[25] Arnold, J., Srinivasan, R., Muttiah, R. S. and Williams, J. R. Large area hydrologic modeling and assessment part I: Model development, J. Am. Water Resour. Assoc., 34 (1), 1998, pp. 73-89.

[26] Avahounlin, F. et Fassinou, E. Contribution à l'élaboration d'une carte de faciès chimiques des eaux souterraines exploitées par la SONEB au Bénin, Mémoire de maîtrise èssciences naturelles, FAST/UAC, Abomey-Calavi, Bénin, 2007, pp. 64.

[27] Dubas, M. et Pigueron, Y. Guide pour l'étude sommaire de petites centrales hydrauliques, manuel de cours, Haute Ecole Spécialisée de Suisse Occidentale, 2009, pp. 48. 